\title{
Family Support in Effort Reduce Hospitalization Reaction in Children of Preschool in Anggrek Room Nganjuk Hospital
}

\author{
Risa Nurhayati ${ }^{1}$, Indasah $^{2}$, \\ Byba Melda Suhita ${ }^{2}$ \\ ${ }^{1}$ Magister of Health Study \\ Program of STIKes Surya Mitra \\ Husada Kediri \\ ${ }^{2}$ Lecturer of STIKes Surya Mitra \\ Husada Kediri \\ ners.risa@gmail.com
}

Received: January 25, 2018

Accepted : May 08, 2018

Published : May 11, 2018

\section{ABSTRACT}

Disease and hospitalization are often the main crises that children face, causing the child to experience trauma. The phenomenon of separation and experience of hospitalized children shows when a child is hospitalized will experience a change in emotional status, as well as parents crying, anxious, angry. Preschool age is very susceptible to the effects of tress during hospitalization, so there is a need for family support. The objective of the study was to explore the support of the family in order to decrease the hospitalization of preschool children in the orchid room of RSUD Nganjuk. The research method used qualitative research with phenomenological approach. Data collection using primary and secondary data then conducted in-depth interviews (indepth interview) with semi-structured questions. Informants as many as 5 people according to the inclusion criteria that researchers make are families who have preschool children, long day 1-3 care, family as the main caregiver, children with medical diagnosis group of internal medicine, children do not have terminal disease, the family is willing to become informants. The results show that family support includes informational support, assessment support, emotional support and instrumental support. But the support has not been maximal because it is influenced by the reaction of children and parents who are varied towards hospitalization along with influencing factors such as child adaptation process, the existence of rooming in, sibling reaction.

Keywords : Family Support, Hospitalization, Preschool.

Copyright @ 2018 STIKes Surya Mitra Husada

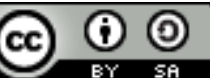

This is an open-acces article distributed under the terms of the Creative Commons Attribution-ShareAlike 4.0 International License. 


\section{INTRODUCTION}

Disease and hospitalization are often the main crises that children face, causing children to experience both short-term and long-term trauma (Wong et al., 2009). The same thing is also conveyed by Hockenberry and Wilson (2014) that the main things that can cause stress and the process of hospitalization is separation from parents, loss of control, and fear of bodily injury and pain. Hospitalization can cause different reactions at every stage of child growth (Wong et al., 2009). The same thing is also conveyed by Hockenberry and Wilson (2014) that the main things that can cause stress and the process of hospitalization is separation from parents, loss of control, and fear of bodily injury and pain.

Based on the results of research conducted by Januarsih (2014) showed from 20 respondents highest frequency of children with severe anxiety level, that is 14 respondents (70\%) and lowest frequency of children with moderate anxiety level, that is 6 respondents (30\%). According Potts and Mandleco (2007) this situation resulted in children and families to be anxious because it must be faced with ignorance of new experiences and situations.

According to Hamid (2008) at this stage of preschool the behavior of loss of control becomes more clear, the child shows more protest attitude loudly. In preschool the child is unable to distinguish between reality and fantasy in all situations. Based on data from the National Association of Children's Hospital in America, 6.5 million children / year are undergoing hospitalization with age less than 17 years (Roberts, 2010). In Indonesia, the number of preschoolers (3-6 years old) based on SUSENAS 2010 is $72 \%$ of the total population of Indonesia estimated at 35 per child under hospitalization and $45 \%$ of them have anxiety (Sumaryoko, 2008). Based on initial data collection, the number of inpatients in the orchid room in September were 217 patients with $21.59 \%$ of pre-school age, the rest were infant (infant), toodler and school.

Jennet and Peterson in Winarsih (2012) suggest that preschool age is particularly vulnerable to the effects of stress and fear during hospitalization. Children under the age of six are less able to think about events as a whole, have not been able to determine behaviors that can overcome a problem they just faced and less understanding of an event experienced. This needs treatment as early as possible, because the delay in handling this anxiety itself will bring a bad reaction to the healing process, especially in children who must get treatment in hospitals that the environment is still foreign to him. If anxiety is not immediately addressed and worsening, then a bigger and tangible reaction is that the child will refuse treatment and treatment, such conditions have a major effect on the duration or process of treatment and treatment and healing of the sick child (Supartini, 2004). If anxiety is not addressed and worsens, the child will refuse treatment and treatment, this condition has a major effect on the duration or process of treatment and treatment and healing of the sick child (Supartini, 2004). If the child experiences stress during hospitalization then the parents experience stress as well. Stress parents can increase child stress is increasing, it takes parent involvement (family support) in care (Hidayat, 2005).

Research conducted by Coyne (2006) on the role of parents in nursing care shows that children during the process of hypocrisy require parental participation and participation in care. Parents have a role to accept the child's condition and provide participation in care. The form of participation is that parents are expected to live with children, behave well and engage in care. When parents are unable to participate in care, then nursing care provided by the nurse may not be able to run optimally. Therefore nurses and parents should work together in minimizing hospitalization reactions in children.

Magnaz, et.al, (2009) in his study of nurse support in elderly with treated children shows that parents receive support from nurses to participate in the care of children. Families need to be aware of the importance of some types of nursing action procedures that require parental support so that nurses can improve the quality of care.

This study aims to explore family support in efforts to reduce the hospitalization of preschool children in the orchid room Nganjuk RSUD. The focus of this study was to explore hospitalization reactions in children and factors affecting children's reactions to 
hospitalization, exploring hospitalization reactions in older people and factors affecting parents' reactions to hospitalization, and family support during the care of sick children.

\section{METHODS}

The type of this research is descriptive phenomenological with qualitative approach with focus of its research directed to applying family support in effort to decrease hospitalization reactions in preschool children in orchid room Nganjuk RSUD in depth. In addition, the qualitative approach is expected to be expressed towards the hospitalization reaction of children and families, family support during the care of sick children in the orchid room Nganjuk RSUD. In this study, data collection methods used by researchers is a semistructured in-depth interview with the time determined by researchers. The process of the interview activity is done first by preparing the interview guidance with semi-structured question form. In the execution of interviews used in-depth interview guides, and mobile (time field) as a recording tool and documentation. The criteria of data validity in this study refers to the four criteria mentioned by Moloeng (2007) namely credibility, transferability, dependability and conformability.

\section{RESULT}

Result of research get 7 big theme that got from result of deep interview (indepth interview) from 5 informant showed 7 theme based on focus of research which among others the process of adaptation of child to hospitalization reaction got in the form of anxious, saturated want to go home, afraid, crowded, crying, cranky there is even 1 informant who states that his child was used not to have fear because often out of the hospital. While related to the existence of rooming in during the hospitalization obtained children from 4 informants almost all will react to cry and fear when parents are not located beside children and left far away but there is 1 informant who states children do not cry if the parents say goodbye to him child. 3 . The third theme is the response of the children to the hospitalization obtained from interviews to 5 informants who showed the child responded to fear, crying when the child performed the procedure of action and the child experienced psychological changes during the hospitalization that is marked the child becomes less cheerful, fussy, sullen, but there is 1 informant who declared his son back cheerful after receiving treatment at the hospital. The next theme is the process of losing as a reaction hospitalisasi parents get when all parents know their children should be treated in the hospital parents feel guilty, confused, sad, no and no money and some even depressed because the informant worried about the radiation effects caused after his son repeatedly performing diagnostic checks.

The fifth theme is the parents show the informant to know the condition of child health, the different anxiety to the severity of the child, anxious to the medical action, the father who served the household duties, whether or not the family visited, the caring process experienced by almost all informants and stated if the process caring there is good but there is 1 informant who states the caring process has not been maximized, as well as women who become the backbone of the family as revealed by one of the informants. The next theme is a sibling reaction in which siblings pay attention to their sick brother over the phone, but there are protest reactions appearing on siblings as revealed by 2 informants. The final theme is family support in which the support includes indoemational support which is indicated by providing information about how important medical action is performed, the informant provides support in the form of attention when finding the child has a complaint, emotional support in the form of praise when his child is cooperative in nursing, instrumental support indicated by the informant providing assistance during the child's need, taking turns babysitting, inviting play and family to prepare the financing that almost all informants use a poor statement. 


\section{DISSCUSION}

The phenomenon of separation and experience of hospitalized children shows that when a child is admitted to the hospital will experience a change in emotional status, as well as parents. The phenomenon of separation causes the child to behave less well, such as crying, aggressive, withdrawing and hipoaktif (Pressley, 2011). Children treated in the hospital also experienced regression. This form of regression is reflected in the desire to be close to the elderly, crying, moaning, sucking the thumb or more seriously is the refusal to eat and excessive motor activity (Bernand and Wilson, 2009).

Disease and hospitalization are often the first crises a child has to face. Children especially during the early years are particularly vulnerable to disease crises and hospitalization due to stress due to changes from normal health and environmental routines, and children have a limited number of coping mechanisms to complete stressors (Wong et al., 2009). The same thing was presented by Rokach (2016) in a report and clinical case review of "Psychological, Emotional and Physical Experiences of Hospitalized Children" that experience hospitalized is usually an anxiety-and even traumatic experience, especially for children, susceptible to the side effects of the presence of illness, and their hospitalization is under pressure that is potentially undesirable by the child thus becoming a consequence for themselves and their families. This is in accordance with the theory presented by Kyle (2008) in general, children are less understood and have little experience of hospitalization, illness and hospital procedures will experience an increase in anxie Previous experience of hospitalization and illness can make preparation either easier or more difficult (if the experience is perceived as negative). The experience of past hospitalizations always creates a reaction for patients, especially children. the more often a child has to do with the hospital, the less anxiety or vice versa it is in accordance with the results of the Pelander and Kilpi studies (2010 cit Utami, 2014). Families often feel anxious about their child's development, treatment and maintenance costs. When children are stressed during the treatment period, parents become stressed out as well, and the stress of the parents will make the child's stress level increases.

The family is one of the basic units that is responsible for preserving the integrity of individual family members that will form a family structure that includes emotional, social, and economic support to its members. The family is highly functional to assist in maintaining the dimensions of communication, emotional and behavioral control, and also helps in problem solving and overcomes the behavior of its individual members (Neena et.al, 2010).

According to Wong et.al, (2009) the presence of parents at all times can help reduce anxiety children. Parents are expected to be involved in nursing activities during the hospital so that parents can participate in care and then create a treatment room such as home situations by decorating the walls using posters or picture cards so that children feel safe when they are in the room. In addition, the familiar environment also increases the child's adjustment to separation. If parents are not able to do caring, they should bring children's favorite items from home to the hospital such as blankets, playgrounds, bottles, cutlery, or clothing. The presence of these dead objects can provide a sense of comfort and tranquility in children. The child's reaction to pain varies according to the child's developmental level (Supartini, 2004). The younger the child is, the more difficult it is for the child to adjust to the experience of being hospitalized (Sacharin, 2001). According to James and Ashwill (2007) the rate of child development affects the child's reaction to the disease. The development of the child at the age of preschool is to form a simple concept of social reality, learn to foster an emotional connection with others and learn to foster good and bad relationships with others. These differences should be considered when planning nursing care. Inpatient preparation and procedures to be performed are based on the growth and development of the child. Childcare in the hospital not only creates problems for the child, but also for the parents. Various kinds of feelings arise in the parents of fear, guilt, stress and anxiety. Feelings of parents should not be ignored because when parents are stressed, this will make him unable to care for his child well and will cause the child will become increasingly stress fear, anxiety and frustration is a feeling expressed by many parents. Fear and anxiety can be related to the seriousness of the 
illness and the medical procedures undertaken. Often the greatest anxiety is related to the trauma and pain that occurs in the child. Feelings of frustration are often associated with procedures and medications, ignorance of hospital regulations, unacceptable feelings, unclear prognosis, or fear of asking questions (Wong et al., 2009).

The results of the study indicate that although parents have a lot of experience about child hospitalization, the feelings of anxiety still arise, this is reinforced by Winarsih (2012) statement that parents who have experience of caring for children will be more anxious especially if the sick child. Parents fear that children experience pain when given nursing actions, this experience has a significant effect on anxiety because experience is a condition in which a person has been in the same situation or condition before. Hospitalization activities not only involve physical exposure alone with the officer or hospital environment, but also happen conditions where a person is in situations and systems that they can not control and experience powerlessness.

In accordance with Hudak and Gallo (1997) then such a situation will affect the level of anxiety parents. When hospitalization begins there will be a role change in the family. The role can be interpreted as a set of behaviors expected by the individual according to his social status. If he is a nurse, the expected role is the role of a nurse rather than a doctor (Asmadi, 2008). In the role change required the support system for children who dihospitalisasi as well as families who play a role in the treatment. The support system will affect the child's reaction during the lifetime, including the family and parenting that the child gets inside his family.

The results of the study by Tamsuri et.al, (2008) show that social support is closely related to anxiety. These results are consistent with Rahmawati (2008) on the effect of family support on anxiety in preschoolers who experience hospitalization indicating there is a strong relationship between family support and anxiety levels experienced by children. The existence of support from the hospital environment as well as from family and relatives can provide meaning for patient and family member. According to Hudak \& Gallo (1997) in Tamsuri et.al, (2008) in families whose children are hospitalized, they may experience anxiety because they find their children sick but they are unable to do anything to help them and feel powerless to provide assistance required.

According Supartini parents will experience fears of the occurrence of something painful or cause suffering in children. When children stress during the care of parents become stress as well, and stress parents will make the child's stress level increases. Anxiety will increase if they are uninformed about the procedure and treatment of the child and its impact on the child's future. Parents react with disbelief especially if the child's illness is sudden and serious. After realizing the state of the child, they will react angrily and feel guilty, often blaming themselves for not being able to care for the child so the child becomes ill.

Jennet and Peterson in Winarsih (2012) suggest that preschool age is particularly vulnerable to the effects of stress and fear during hospitalization. The environment and new people will cause stress to affect children's development, Brown and Semple research results in Ferguson (2013) show that the environment and unknown people for children aged 3 to 5 years can decrease motor perception, verbal behavior and encourage children of aggressive and emotional behavior in addition to the results of research Grasso, Ford, Briggs (2013) also showed that exposure to stress or trauma can have a serious impact on child development, disturbed development can lead to a number of functional disorders in emotions, cognitive, behavioral, and relationships interpersonal.

Sibling is very affected in the face of family members who are being treated in hospital. Sibling will feel jealous, angry, hateful, jealous and guilty. This is because suddenly the attention of the family is fixed on the sick brother so that sibling will feel neglected. In the opinion of Simon, (1993) quoted by Wong et.al (2009) based on 45 sibling experience examined perceptions, they experience stress level with stress in children who undergo hospitalization.

Jennet and Peterson in Winarsih (2012) suggest that preschool age is particularly vulnerable to the effects of stress and fear during hospitalization. The environment and new people will cause stress to affect children's development, Brown and Semple research results in Ferguson (2013) show that the environment and unknown people for children aged 3 to 5 
years can decrease motor perception, verbal behavior and encourage children of aggressive and emotional behavior in addition to the results of research Grasso, Ford, Briggs (2013) also showed that exposure to stress or trauma can have a serious impact on child development, disturbed development can lead to a number of functional disorders in emotions, cognitive, behavioral, and relationships interpersonal.

It is therefore important for nurses to not only serve as nursing care providers to clients in getting healing illness but also to play a role in fulfilling the client's health needs holistically, through technical ability, emotional, psychological, spiritual and social support. Nurses who are in charge of providing nursing care should develop caring behavior, caring nurses mean the nurse is able to reduce stress or trauma patients while undergoing hospitalization (Mulyaningsih, 2011).

Friedman (2010) explains that family support can be attitudes, actions and acceptance of sick people. The family also serves as a support system for its members and family members see that people who are supportive, always ready to provide help and assistance if needed. According to Smet (1994), family support is the help and encouragement given by the family to its members where such support as a mediator variable demonstrates a coping facility during a time of crisis.

Family support can have a positive effect on the health of family members. This form of support can be given in two ways: directly and indirectly. Directly this support will give encouragement to its members to behave healthily, while indirectly the support received from others will reduce tension or depression so as not to cause disruption (Kaplan \& Sadock, 2007). This result is consistent with research from Rahmawati (2008) on the effect of family support on anxiety in pre-school children who experienced hospitalization indicates that there is a strong relationship between family support and anxiety levels experienced by children. The existence of support from the hospital environment as well as from family and relatives can provide meaning for patient and family member.

\section{CONCLUSION}

The conclusions obtained based on the results of the research known to the reaction of children to hospitalization and factors that influence very varied, the proposition obtained is no difference reaction hospitalization in every child growth. The reaction of parents to hospitalization and the factors that influence it very varied proposition obtained is the reaction of hospitalization of parents depending on the history of childhood illness. And the last conclusion based on the results of family support research during the treatment of sick children varied, the proposition obtained is good family support can minimize the reaction of hospitalization of children during illness.

\section{SUGGEST}

1. For the next researcher

It is hoped to develop research by triangulating methods so that new phenomena can emerge

2. For institutions where the research

The results of this study as input materials for hospitals in applying family support so as to improve the quality of nursing services, decorate the room so that patients do not feel afraid and restless in the hospital, and in performing medical procedures can apply the principle of atraumatic care for hospitalization reaction perceived by children and parents can be minimized and the process of growing the child is expected to keep going.

3. For educational institutions

The results of this study can provide input to the institution as useful information and can be used as a reference of further research and also develop a scientific repertoire of children. 
4. For informants

Can optimize the role of the family during the child underwent hospitalization so that the hospitalization reaction felt by the family and children can be minimized and the family can still run its role in accordance with family duties.

\section{REFERENCES}

Bernand, W,K., \& Wilson, W.C. (2009). Psychological Effects Of Physical Illness And Hospitalization On The Child And The Family. J.H.K.C. Psych, 3, 9-18.

Hamid, A. (2008). Buku Ajar Riset Keperawatan: Konsep, Etika, \& Instrumentasi, Edisi 2 . Jakarta: EGC.

Hidayat, A.A.A. (2005). Pengantar Ilmu Keperawatan Anak I. Jakarta: Salemba Medika.

Hockenberry, M.J., \& Wilson, D. (2007). Wong Nursing Care Of Infant And Children. Eight Edition, Mosby: Evolve Elsevier.

James, S.R. \& Ashwill, J.W. (2007). Nursing Care Of Children : Principles \& Practice. Third Edition. St. Louis : Saunders Elsevier.

Januarsih, T. (2014). Pengaruh Terapi Bermain (Origami) Dalam Mengurani Tingkat Kecemasan Akibat Hospitalisasi Pada Anak Usia Prasekolah Di RSUD Karanganyar . Skripsi. Surakarta: Sekolah Tinggi Ilmu Kesehatan (STIKes) 'Aisyiyah.

Kyle, Terri, Carman, \& Susan. (2008). Buku Ajar Keperawatan Pediatri. Edisi 2. Vol.1. Jakarta: EGC.

Mahnaz, S., Heidari, S., Salemi, S., Rahmani, M., \& Shoghi, M. (2009). Nursing Support For Parents Of Hospitalized Children. Issues in Comprehensive Pediatric Nursing, 32,120-130.

Moleong, L. (2007). Metodologi Penelitian Kualitatif. Bandung: PT Remaja Rosdakarya.

Potts, N.L \& Mandleco, B.L. (2007). Pediatric Nursing: Caring For Children And Their Families. Canada: Thomson, Delmar Learning.

Pressley, T. (2011). An Overview Of Separation Phenomenom And The Experience Of Hospitalization For Children. Jefferson Journal Of Psychiatry. 37-42.

Roberts, C., A. (2010). "Unaccompanied Hospitalized Children: A Review Of The Literature And Incidence Study”. Journal Of Pediatric Nursing, 25, 470-476.

Rokach, Ami. (2016). Psychological, Emotional And Physical Experiences Of Hospitalized Children Clinical Case Reports And Reviews. Volume 2(4): 399-401.

Sacharin, M. R. (2001). Prinsip Keperawatan Pediatrik. (Principles Of Pediatric Nursing) Diterjemahkan Oleh Maulany. Jakarta: EGC.

Survei Kesehatan Nasional (SUSENAS). (2010). Jumlah Anak Usia Prasekolah Di Indonesia. https://www.unicef.org/indonesia/id/a3_b_ringkasan_kajian_pendidikan.pdf. Diakses Tanggal 20 Juni 2017. 
Sumaryoko. (2008). Hubungan Tingkat Pendidikan Dengan Tingkat Pengetahuan Perawat Tentang Terapi Bermain Pada Anak Dirumah Sakit Se Wilayah Boyolali. Surakarta : Univ Muhamadiyah Surakarta.

Supartini, Y. (2004). Buku Ajar Konsep Dasar Keperawatan Anak. Jakarta: EGC.

Tamsuri, A., Lenawati, H., \& Puspitasari, H. (2008). Faktor Faktor Yang Mempengaruhi Kecemasan Pada Ibu Saat Menghadapi Hospitalisasi Pada Anak Di Ruang Anak RSUD Pare Kediri. Skripsi. Pare: Akademi Keperawatan Pamenang.

Utami, \& Yuli. (2014). Dampak Hospitalisasi Terhadap Perkembangan Anak. Jurnal Ilmiah Vol.2 No. 2.

Winarsih, B. D. (2012). Hubungan Peran Serta Orang Tua Dengan Dampak Hospitalisasi Pada Anak Usia Prasekolah Di RSUD RA Kartini Jepara. Tesis. Fakultas Magister Keperawatan. Universitas Indonesia.

Wong, D.L., Hockenberry, \& Marylin J. (2009). Wong's Nursing Care Of Infants And Children. St Louis, Missouri: Mosby inc. 